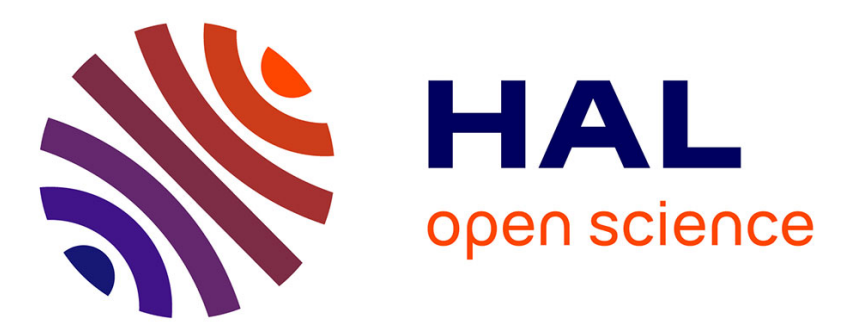

\title{
Increase of available soil silicon by Si-rich manure for sustainable rice production
}

Zhaoliang Song, Hailong Wang, Peter Strong, Shengdao Shan

\section{To cite this version:}

Zhaoliang Song, Hailong Wang, Peter Strong, Shengdao Shan. Increase of available soil silicon by Si-rich manure for sustainable rice production. Agronomy for Sustainable Development, 2014, 34 (4), pp.813-819. 10.1007/s13593-013-0202-5 . hal-01234822

\section{HAL Id: hal-01234822 \\ https://hal.science/hal-01234822}

Submitted on 27 Nov 2015

HAL is a multi-disciplinary open access archive for the deposit and dissemination of scientific research documents, whether they are published or not. The documents may come from teaching and research institutions in France or abroad, or from public or private research centers.
L'archive ouverte pluridisciplinaire HAL, est destinée au dépôt et à la diffusion de documents scientifiques de niveau recherche, publiés ou non, émanant des établissements d'enseignement et de recherche français ou étrangers, des laboratoires publics ou privés. 


\title{
Increase of available soil silicon by Si-rich manure for sustainable rice production
}

\author{
Zhaoliang Song • Hailong Wang • Peter James Strong • \\ Shengdao Shan
}

Accepted: 22 November 2013 / Published online: 24 December 2013

(C) INRA and Springer-Verlag France 2013

\begin{abstract}
Depletion of bioavailable silicon, $\mathrm{Si}$, in paddy soils can decrease the yields of rice. A potential solution is to amend soil with Si-rich organic wastes such as manure from animals fed with rice crop residues. Here, we studied Si in soils from 2000 to 2010 field experiments without manure, with 5 and 10 years of manure, in Eastern China. Results showed that available $\mathrm{Si}$ in soils increased from 130 to $270 \mathrm{mg} \mathrm{kg}^{-1}$ after 10 years of manure amendment. This finding is explained either by direct input of available $\mathrm{Si}$ or by $\mathrm{Si}$ produced by mineralization of Si minerals. To conclude, our results show that amending soil with Si-rich manure in the long term is a solution for sustainable rice production.
\end{abstract}

\footnotetext{
Z. Song $(\bowtie) \cdot H$. Wang $\cdot$ S. Shan

Zhejiang Provincial Key Laboratory of Carbon Cycling in Forest Ecosystems and Carbon Sequestration, Zhejiang Agricultural and Forestry University, Lin'an, Hangzhou 311300, China

e-mail: songzhaoliang78@163.com

H. Wang

e-mail: nzhailongwang@gmail.com

Z. Song $\cdot$ H. Wang $\cdot$ S. Shan

School of Environment and Resources, Zhejiang Agricultural and Forestry University, No. 88 North Huancheng Road, Lin'an, Zhejiang 311300, China

Z. Song

State Key Laboratory of Environmental Geochemistry, Institute of Geochemistry, Chinese Academy of Sciences,

Guiyang 550002, China

\section{P. J. Strong}

Centre for Solid Waste Bioprocessing, Schools of Civil and Chemical Engineering, The University of Queensland, St Lucia 4072, Australia
}

Keywords Silicon bioavailability · Fractionation · Noncrystalline Si · Paddy soil · Pig manure · Sustainable rice production

\section{Introduction}

Rice is the staple food for more than a half of the world's population and has a global distribution area of 155 million ha. More than $90 \%$ of the distribution area is located in Asia, comprising China, India, and Indonesia (Van Soest 2006; Kögel-Knabner et al. 2010). Silicon can improve the quality and yield of rice and other cereals (Matichenkov and Calvert 2002; Richmond and Sussman 2003) by enhancing plant resistance to pests (Nakata et al. 2008) and pathogens (Rodrigues et al. 2003), improving drought resistance (Gong et al. 2005), salt tolerance (Tuna et al. 2008), and heavy metal tolerance (Liang et al. 2005) as well as improving soil nutrient availability (Ma and Takahashi 1991). Rice takes up more Si than other nutrients such as nitrogen during its growth (Van der Vorm 1980; Prakash 2002). Annual rice removal of $\mathrm{Si}$ from soils was estimated to range from 205 to $611 \mathrm{~kg} \mathrm{ha}^{-1}$, of which approximately $80 \%$ was in the straw (Prakash 2002; Wickramasinghe and Rowell 2006). Thus, depletion of bioavailable Si in paddy soils would occur if crop residues were not incorporated back and cause the decline or stagnation of crop yields (Savant et al. 1997). Silicon fertilization is becoming an increasingly accepted measure in rice and other cereal production via incorporating crop residues into the soil or applying an external source of $\mathrm{Si}$ (Savant et al. 1997; Matichenkov and Calvert 2002). 
Rice production generates the largest amount of crop residues globally, in the order of 330 million tons annually (Van Soest 2006). The bran, straw, and hulls of rice are usually rich in $\mathrm{Si} \mathrm{(about} 5 \%$ ) and serve as the main feed for animals such as pigs in China and other rice-producing countries (Van Soest 2006; Wickramasinghe and Rowell 2006). As Si is poorly absorbed or digested by animals, the Si content in animal manure from rice-producing areas is generally higher than that from other areas, 5 to $20 \mathrm{~g} \mathrm{~kg}^{-1}$ total $\mathrm{Si}$ (compared to $5 \mathrm{~g} \mathrm{~kg}^{-1}$ total Si) (this study; Van Soest 2006). Therefore, rice residues (Wickramasinghe and Rowell 2006) as well as animal manure from rice-producing areas may therefore serve as a soil supplement to improve soil available Si content and aid rice production.

Besides primary and secondary crystalline and shortrange ordered silicates, $\mathrm{Si}$ is also present as water-soluble $\mathrm{Si}$, adsorbed Si, and amorphous Si (Kurtz et al. 2002). Although various Si pools show contrasting reactivities water as well as soil solutions, they can be transformed under certain conditions (Sommer et al. 2006). For example, acidification may disintegrate clay minerals and release $\mathrm{Si}$ into soil solution in very acid soils, while the released Si may also precipitate at mineral surfaces forming amorphous Si under other $\mathrm{pH}$ conditions (Sommer et al. 2006). The impact of climatic conditions (White and Blum 1995; Sommer et al. 2006), parent material (Höhn et al. 2008), and plant species (Cornelis et al. 2010) on the transformation and uptake of $\mathrm{Si}$ in soils has been demonstrated. However, the transformation and fate of external $\mathrm{Si}$ in soils remain unclear. This study investigated the effects of Si-rich pig manure amendment on transformation and bioavailability of noncrystalline $\mathrm{Si}$ in a paddy soil. The purposes of the study are to assess the fate of Si derived from pig manure and to provide an example for the efficient use of organic wastes in crop production.

\section{Materials and methods}

In order to test the fractionation and bioavailability of noncrystalline $\mathrm{Si}$ in a paddy soil amended with Si-rich pig manure, a 10-year field experiment with two rice cropping systems per year from 2000 to 2010 was conducted at the Mabaoliang farm, Pinghu City, Zhejiang Province, Eastern China $\left(30^{\circ} 39^{\prime} 43^{\prime \prime} \mathrm{N}, 121^{\circ} 00^{\prime} 59^{\prime \prime} \mathrm{E}\right)$. The site has an altitude of about $6 \mathrm{~m}$ and a subtropical climate controlled by the East Asian monsoon. The average annual temperature is $16^{\circ} \mathrm{C}$, and the annual rainfall is approximately $1,170 \mathrm{~mm}$. The soil is composed of $25 \%$ sand, $63 \%$ silt, and $12 \%$ clay and classified as Gleyed paddy soil according to the Chinese soil classification system and Gleysols according to the Food and Agriculture Organization soil classification system. The experiment trial site was reclaimed and planted with rape, alfalfa, and rice for more than 20 years prior to the experiment. The initial properties of the surface soil $(0-20 \mathrm{~cm}$ depth) were as follows: $\mathrm{pH} 6.12 \pm 0.13$, soil organic matter content of $55.16 \pm$ $3.27 \mathrm{~g} \mathrm{~kg}^{-1}, \mathrm{P}$ content of $1.64 \pm 0.17 \mathrm{~g} \mathrm{~kg}^{-1}$, total $\mathrm{SiO}_{2}$ of $603.8 \mathrm{~g} \mathrm{~kg}^{-1}$, and available Si of $142.7 \mathrm{mg} \mathrm{kg}^{-1}$.

The area of each plot is approximately $66.7 \mathrm{~m}^{2}$, with a length of $10 \mathrm{~m}$ and a width of $6.67 \mathrm{~m}$. The experiment was conducted with three replications. The long-term Si-rich pig manure fertilization experiment was based on normal chemical fertilization with full recommended $\mathrm{N}, \mathrm{P}$, and $\mathrm{K}$ fertilizer doses of 120-24-36 and 90-18-27 $\mathrm{kg} \mathrm{ha}^{-1}$ in early and late season rice, respectively. The Si-rich pig manure fertilization experiment was conducted with the following three treatments: control (without manure), 5-year manure, and 10year manure. The rate of manure application was $35 \mathrm{Mg} \mathrm{ha}^{-1}$ year $^{-1}$. The pig manure had a $\mathrm{pH}$ value of 7.50 \pm 0.40 , total organic matter content of $480 \pm 12 \mathrm{~g} \mathrm{~kg}^{-1}$, total P content of $7.3 \pm 2.3 \mathrm{~g} \mathrm{~kg}^{-1}$, and total Si content of $8.5 \pm$ $1.5 \mathrm{~g} \mathrm{~kg}^{-1}$.

The mature crop was harvested manually at $5 \mathrm{~cm}$ above the ground level. The annual yields of rice grain ranged from 10 to $12 \mathrm{Mg} \mathrm{ha}^{-1}$. The ratio of straw to grain of rice was approximately 1.1. The Si content of rice was $23.1 \pm 3.2 \mathrm{~g} \mathrm{~kg}^{-1}$. Annual rice removal of $\mathrm{Si}$ from soils was estimated to range from 200 to $370 \mathrm{~kg} \mathrm{ha}^{-1}$.

\subsection{Soil sampling and treatment}

Soil samples from were hand collected horizontally from five depths: 0 to 10,10 to 20,20 to 30,30 to 40 , and 40 to $70 \mathrm{~cm}$. For soil $\mathrm{pH}$ analyses, samples were air-dried, crushed, and passed through a 2-mm sieve (after removing visible stones, roots, and crop residues). Subsamples were ground to a size that would pass a 100-mesh sieve and then used for chemical analyses to determine contents of other parameters such as organic matter and different fractions of noncrystalline $\mathrm{Si}$.

\subsection{Physical and chemical analysis}

Soil $\mathrm{pH}$ was determined in a ratio of 1:2.5 soil/water suspension with a PHS-3C precision $\mathrm{pH}$ meter. Organic carbon was analyzed using a wet oxidation method with dipotassium chromate and concentrated sulfuric acid to determine the chemical oxygen demand, from which the soil organic matter content was calculated (Nelson and Sommers 1982). Soil samples were fused in nickel crucible with sodium hydroxide at $650{ }^{\circ} \mathrm{C}$ and neutralized with dilute hydrochloric acid. The concentrations of $\mathrm{Si}$ and $\mathrm{P}$ in the prepared sample solution 
were determined colorimetrically by the molybdate-ascorbic acid method (Mortlock and Froelich 1989; Murphy and Riley 1962). Available Si in soil was extracted with acid sodium acetate ( $\mathrm{Lu} 2000)$.

\subsection{Fractionation of noncrystalline $\mathrm{Si}$}

Four "operationally defined" soil noncrystalline $\mathrm{Si}$ fractions including acid $\mathrm{Na}$ acetate- $\mathrm{Si}, \mathrm{H}_{2} \mathrm{O}_{2}-\mathrm{Si}, \mathrm{NH}_{2} \mathrm{OH} \cdot \mathrm{HCl}-\mathrm{Si}$, or $\mathrm{NaOH}-\mathrm{Si}$ were isolated in sequence (Table 1) to represent available $\mathrm{Si}$, organic $\mathrm{Si}, \mathrm{Fe}-\mathrm{Mn}$ oxide $\mathrm{Si}$, and amorphous $\mathrm{Si}$, respectively. A portion of each extract was pipetted into a $50-\mathrm{mL}$ centrifuge tube and centrifuged (Sorvall, Model $\mathrm{RC} 2-\mathrm{B}$ ) at $16,300 \mathrm{~g}$ at $0{ }^{\circ} \mathrm{C}$ for $10 \mathrm{~min}$; Si was then determined colorimetrically using the molybdate-ascorbic acid procedure (Mortlock and Froelich 1989). All Si measurements were done in triplicate. The data were analyzed by ANOVA, and means were compared with Duncan's test using the SPSS software (SPSS 11.5 for windows).

\section{Results and discussion}

\subsection{Manure impact on soil parameters}

The $\mathrm{pH}$ value in surface soil of 0 to $10 \mathrm{~cm}$ depth increased from 5.92 to 7.18 with the cumulative additions of pig manure (Table 2). As a major component of soil, $\mathrm{SiO}_{2}$ content did not show an increasing trend with manure amendment in most depths of soil profiles. Soil organic matter and total $\mathrm{P}$ content in upper soil profiles such as 0 to $30 \mathrm{~cm}$ depth increased with the cumulative additions of pig manure from lower than 52 to $63 \mathrm{~g} \mathrm{~kg}^{-1}$ and from lower than $1.6 \mathrm{~g} \mathrm{~kg}^{-1}$ to higher than $4.6 \mathrm{~g} \mathrm{~kg}^{-1}$, respectively. Available $\mathrm{Si}$ throughout soil profiles increased from
$133 \mathrm{mg} \mathrm{kg}^{-1}$ to higher than $267 \mathrm{mg} \mathrm{kg}^{-1}$ with manure amendment. Generally, the impact of manure amendment on soil parameters in upper soils such as surface soil was more significant than that in bottom soils, as soil organic matter may degrade, and mineral elements may deposit or be adsorbed by secondary minerals during their vertical transport with irrigation water. However, the fluctuation of $\mathrm{pH}$ and $\mathrm{SiO}_{2}$ in bottom soils may be affected by other factors such as groundwater level fluctuation and soil heterogeneity.

\subsection{Manure impact on soil noncrystalline Si distribution}

Generally, major noncrystalline $\mathrm{Si}$ fractions in soils were $\mathrm{NaOH}-\mathrm{Si}$ and $\mathrm{NH}_{2} \mathrm{OH} \cdot \mathrm{HCl}-\mathrm{Si}$, while minor amounts of acid $\mathrm{Na}$ acetate- $\mathrm{Si}$ and $\mathrm{H}_{2} \mathrm{O}_{2}-\mathrm{Si}$ were also present (Figs. 1, 2, 3, and 4).

Acid $\mathrm{Na}$ acetate- $\mathrm{Si}$ in soil profiles increased from $130 \mathrm{mg} \mathrm{kg}^{-1}$ to higher than $270 \mathrm{mg} \mathrm{kg}^{-1}$ with the cumulative additions of pig manure (Fig. 2). The percentage of acid Na acetate-Si in the four noncrystalline $\mathrm{Si}$ forms throughout soil profiles showed a similar increasing trend. The percentage of acid $\mathrm{Na}$ acetate-Si increased from $3.4 \%$ to higher than $6 \%$. The increasing trend is more obvious in the upper part of soil profiles such as 0 to $20 \mathrm{~cm}$ than that in the bottom soil. The increase soil of acid $\mathrm{Na}$ acetate-Si content and percentage is due to the high efficiency of available Si release from manure degradation.

$\mathrm{H}_{2} \mathrm{O}_{2}-\mathrm{Si}$ content in soils of $0-40 \mathrm{~cm}$ increased from lower than 215 to $245 \mathrm{mg} \mathrm{kg}^{-1}$ with the cumulative additions of pig manure due to organic Si input from manure (Fig. 3). However, the mass ratio of acid $\mathrm{Na}$ acetate- $\mathrm{Si} / \mathrm{H}_{2} \mathrm{O}_{2}-\mathrm{Si}$ increased from 0.62 to 1.09 with the cumulative additions of pig manure in the upper parts $(0$ to $20 \mathrm{~cm}$ ) of soil profiles as the organic $\mathrm{Si}$

Table 1 Soil noncrystalline Si fractionation procedure modified after Tessier et al. (1979), Lu (2000), and Kurtz et al. (2002)

\begin{tabular}{|c|c|c|c|}
\hline Step & Si fraction & Conditions & Characteristics \\
\hline 1 & Acid $\mathrm{Na}$ acetate- $\mathrm{Si}$ & $\begin{array}{l}\text { Add } 30 \mathrm{~mL} 1 \mathrm{~mol} \mathrm{~L}^{-1} \text { acid } \mathrm{Na} \text { acetate buffer solution } \\
\text { at } \mathrm{pH} 4.0 \text { to } 0.75 \mathrm{~g} \text { soil in a } 50-\mathrm{mL} \text { centrifuge tube, } \\
\text { shake for } 16 \mathrm{~h} \text {, centrifuge }\end{array}$ & $\begin{array}{l}\text { Bioavailable and mobile } \\
\text { Si directly exchangeable } \\
\text { with soil solution }\end{array}$ \\
\hline 2 & $\mathrm{H}_{2} \mathrm{O}_{2}-\mathrm{Si}$ & $\begin{array}{l}\text { Add } 5 \mathrm{~mL} 30 \% \mathrm{H}_{2} \mathrm{O}_{2} \text { to the residue from step } 1 \text {, } \\
\text { heat to } 85 \pm 2{ }^{\circ} \mathrm{C} \text { for } 1 \mathrm{~h} \text { twice, add } 30 \mathrm{~mL} 1 \\
\text { mol L } \mathrm{L}^{-1} \text { acid } \mathrm{Na} \text { acetate buffer solution at } \mathrm{pH} 4.0 \text {, } \\
\text { shake for } 16 \mathrm{~h} \text {, centrifuge }\end{array}$ & $\begin{array}{l}\text { Labile Si associated with } \\
\text { humic compounds }\end{array}$ \\
\hline 3 & $\mathrm{NH}_{2} \mathrm{OH} \cdot \mathrm{HCl}-\mathrm{Si}$ & $\begin{array}{l}\text { Add } 30 \mathrm{~mL} 0.5 \mathrm{~mol} \mathrm{~L}^{-1} \mathrm{NH}_{2} \mathrm{OH} \cdot \mathrm{HCl} \text { to the residue } \\
\text { from step 2, wrap the tubes with foil, shake for } \\
16 \mathrm{~h} \text {, centrifuge }\end{array}$ & $\begin{array}{l}\text { Labile Si chemisorbed to } \\
\text { Fe and Mn compounds }\end{array}$ \\
\hline 4 & $\mathrm{NaOH}-\mathrm{Si}$ & $\begin{array}{l}\text { Add } 30 \mathrm{~mL} 0.5 \mathrm{~mol} \mathrm{~L} \mathrm{~L}^{-1} \mathrm{NaOH} \text { to the residue from step } 3 \text {, } \\
\text { treat with ultrasonic bath for } 1 \mathrm{~h} \text {, shake for } 16 \mathrm{~h} \text {, centrifuge }\end{array}$ & $\begin{array}{l}\text { Weakly labile Si fixed in } \\
\text { noncrystalline or short-range } \\
\text { crystal-order silicates }\end{array}$ \\
\hline
\end{tabular}


Table 2 Selected physical and chemical properties of the soils used in this study

\begin{tabular}{|c|c|c|c|c|c|c|}
\hline Depth $(\mathrm{cm})$ & Treatment & $\mathrm{pH}$ & $\mathrm{SiO}_{2}\left(\mathrm{~g} \mathrm{~kg}^{-1}\right)$ & Soil organic matter $\left(\mathrm{g} \mathrm{kg}^{-1}\right)$ & $\mathrm{P}\left(\mathrm{g} \mathrm{kg}^{-1}\right)$ & Available Si (mg kg $\left.{ }^{-1}\right)$ \\
\hline \multirow[t]{3}{*}{$0-10$} & No manure & $5.92 \pm 0.08 \mathrm{c}$ & $601 \pm 2 a$ & $52.0 \pm 4.0 \mathrm{~b}$ & $1.59 \pm 0.06 \mathrm{c}$ & $133 \pm 10 \mathrm{c}$ \\
\hline & 5-year manure & $6.67 \pm 0.14 \mathrm{~b}$ & $605 \pm 14 a$ & $60.0 \pm 5.3 \mathrm{ab}$ & $2.56 \pm 0.27 b$ & $162 \pm 10 \mathrm{~b}$ \\
\hline & 10-year manure & $7.18 \pm 0.14 \mathrm{a}$ & $606 \pm 18 \mathrm{a}$ & $63.2 \pm 3.6 \mathrm{a}$ & $4.65 \pm 0.66 \mathrm{a}$ & $267 \pm 24 a$ \\
\hline \multirow[t]{3}{*}{$10-20$} & No manure & $6.40 \pm 1.03 \mathrm{a}$ & $620 \pm 36 a$ & $47.3 \pm 5.6 \mathrm{~b}$ & $1.58 \pm 0.04 \mathrm{~b}$ & $149 \pm 16 \mathrm{c}$ \\
\hline & 5-year manure & $7.16 \pm 0.84 \mathrm{a}$ & $620 \pm 15 a$ & $59.5 \pm 6.4 \mathrm{a}$ & $2.03 \pm 0.78 b$ & $188 \pm 8 b$ \\
\hline & 10-year manure & $7.29 \pm 0.08 \mathrm{a}$ & $618 \pm 6 a$ & $62.1 \pm 5.8 \mathrm{a}$ & $4.96 \pm 0.05 \mathrm{a}$ & $247 \pm 17 \mathrm{a}$ \\
\hline \multirow[t]{3}{*}{$20-30$} & No manure & $7.23 \pm 0.64 \mathrm{a}$ & $624 \pm 29 a$ & $31.1 \pm 6.9 \mathrm{~b}$ & $1.28 \pm 0.64 b$ & $195 \pm 19 \mathrm{c}$ \\
\hline & 5-year manure & $7.82 \pm 0.48 \mathrm{a}$ & $642 \pm 29 \mathrm{a}$ & $42.0 \pm 8.6 \mathrm{ab}$ & $1.51 \pm 0.25 b$ & $236 \pm 12 b$ \\
\hline & 10 -year manure & $7.73 \pm 0.79 \mathrm{a}$ & $624 \pm 6 \mathrm{a}$ & $47.3 \pm 7.0 \mathrm{a}$ & $3.97 \pm 1.93 \mathrm{a}$ & $279 \pm 14 \mathrm{a}$ \\
\hline \multirow[t]{3}{*}{$30-40$} & No manure & $7.59 \pm 0.07 \mathrm{~b}$ & $615 \pm 12 \mathrm{a}$ & $13.4 \pm 8.4 \mathrm{a}$ & $0.84 \pm 0.24 \mathrm{a}$ & $239 \pm 6 b$ \\
\hline & 5-year manure & $8.07 \pm 0.01 \mathrm{a}$ & $646 \pm 22 a$ & $17.4 \pm 4.5 \mathrm{a}$ & $1.06 \pm 0.65 \mathrm{a}$ & $262 \pm 16 \mathrm{a}$ \\
\hline & 10-year manure & $8.08 \pm 0.08 \mathrm{a}$ & $639 \pm 24 a$ & $23.2 \pm 4.2 \mathrm{a}$ & $2.04 \pm 1.93 \mathrm{a}$ & $263 \pm 15 a$ \\
\hline \multirow[t]{3}{*}{$40-70$} & No manure & $7.68 \pm 0.09 b$ & $621 \pm 7 b$ & $8.6 \pm 0.8 \mathrm{a}$ & $0.63 \pm 0.10 \mathrm{a}$ & $261 \pm 7 b$ \\
\hline & 5-year manure & $8.01 \pm 0.07 \mathrm{a}$ & $637 \pm 3 a$ & $6.4 \pm 0.5 \mathrm{a}$ & $0.67 \pm 0.04 \mathrm{a}$ & $274 \pm 12 b$ \\
\hline & 10-year manure & $7.94 \pm 0.09 \mathrm{a}$ & $642 \pm 12 \mathrm{a}$ & $8.9 \pm 2.3 \mathrm{a}$ & $0.64 \pm 0.35 \mathrm{a}$ & $297 \pm 6 a$ \\
\hline
\end{tabular}

Values followed by the same letter of a soil depth within the same column are not significantly different at $P<0.05$

released to soil may degrade to form water-soluble or exchangeable inorganic Si.

$\mathrm{NH}_{2} \mathrm{OH} \cdot \mathrm{HCl}-\mathrm{Si}$ content in soils of most depths except 30 $40 \mathrm{~cm}$ increased slightly from lower than 620 to $650 \mathrm{mg} \mathrm{kg}^{-1}$ during the first 5 years of manure amendment and declined to lower than $570 \mathrm{mg} \mathrm{kg}^{-1}$ during the next 5 years of manure amendment (Fig. 4). The first increase of $\mathrm{NH}_{2} \mathrm{OH} \cdot \mathrm{HCl}-\mathrm{Si}$ content in soils is probably due to the high efficiency of $\mathrm{Fe}-\mathrm{Mn}$ oxides in adsorption of bioavailable Si released from manure degradation. However, the late decline of $\mathrm{NH}_{2} \mathrm{OH} \cdot \mathrm{HCl}-\mathrm{Si}$ content in soils is probably the result of $\mathrm{Fe}-\mathrm{Mn}$ oxide dissolution under high organic acid conditions (Chen et al. 2003) created with incomplete degradation of pig manure. The mass ratio of acid $\mathrm{Na}$ acetate- $\mathrm{Si} / \mathrm{NH}_{2} \mathrm{OH} \cdot \mathrm{HCl}-\mathrm{Si}$ increased from 0.21 to 0.46 with the cumulative additions of pig manure in the middle to upper parts $(0$ to $40 \mathrm{~cm})$ of soil profiles

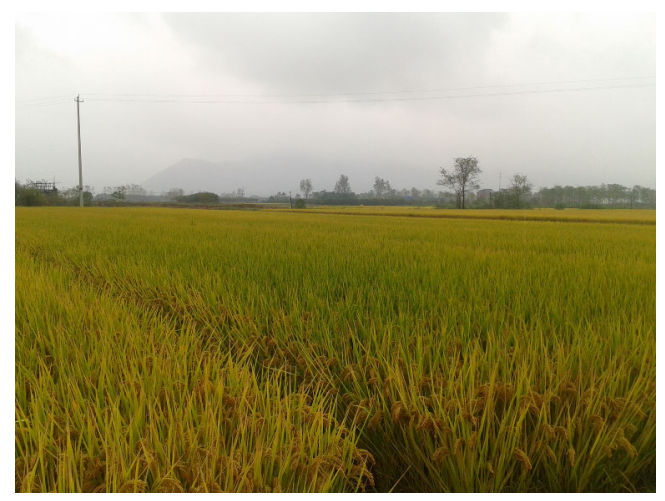

Fig. 1 Extensive and intensive production of rice in China due to $\mathrm{Fe}-\mathrm{Mn}$ oxide dissolution under high organic acid conditions (Chen et al. 2003).
Acid Na-acetate-Si $\left(\mathrm{mg} \mathrm{kg}^{-1}\right)$
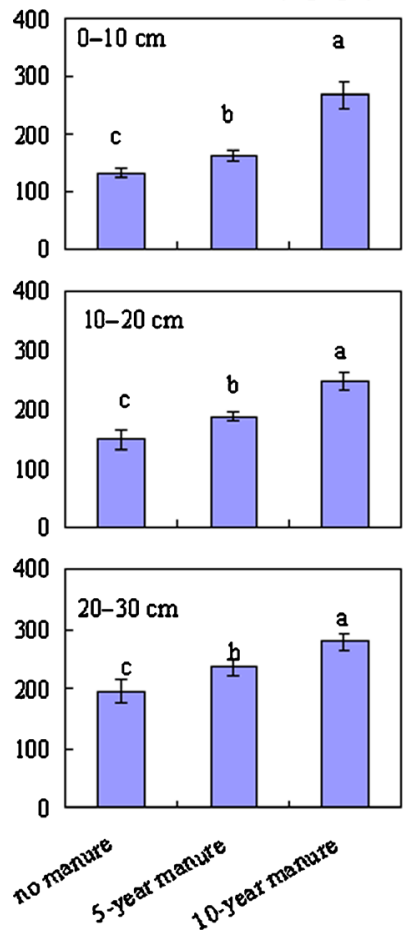

Acid $\mathrm{Na}$-acetate-Si $\left(\mathrm{mg} \mathrm{kg}^{-1}\right)$
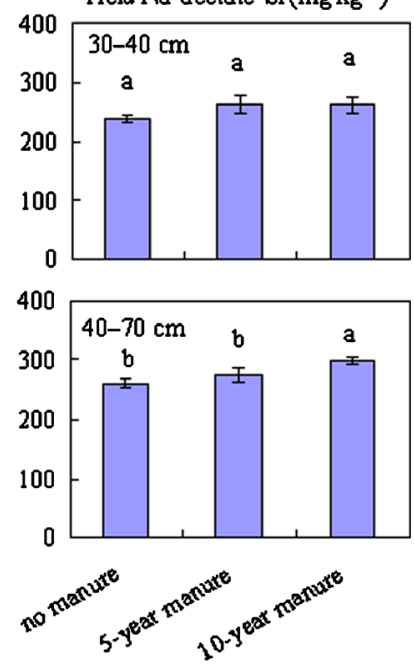

Fig. 2 Distribution of acid Na acetate-Si in soils of different depths after 0 to 10 years of manure amendment. Values followed by the same letter of a soil depth within a figure are not significantly different at $P<0.05$. Acid $\mathrm{Na}$ acetate-Si in soil profiles increased from $130 \mathrm{mg} \mathrm{kg}^{-1}$ to higher than $270 \mathrm{mg} \mathrm{kg}^{-1}$ with the cumulative additions of pig manure due to the high efficiency of available Si release from manure degradation 

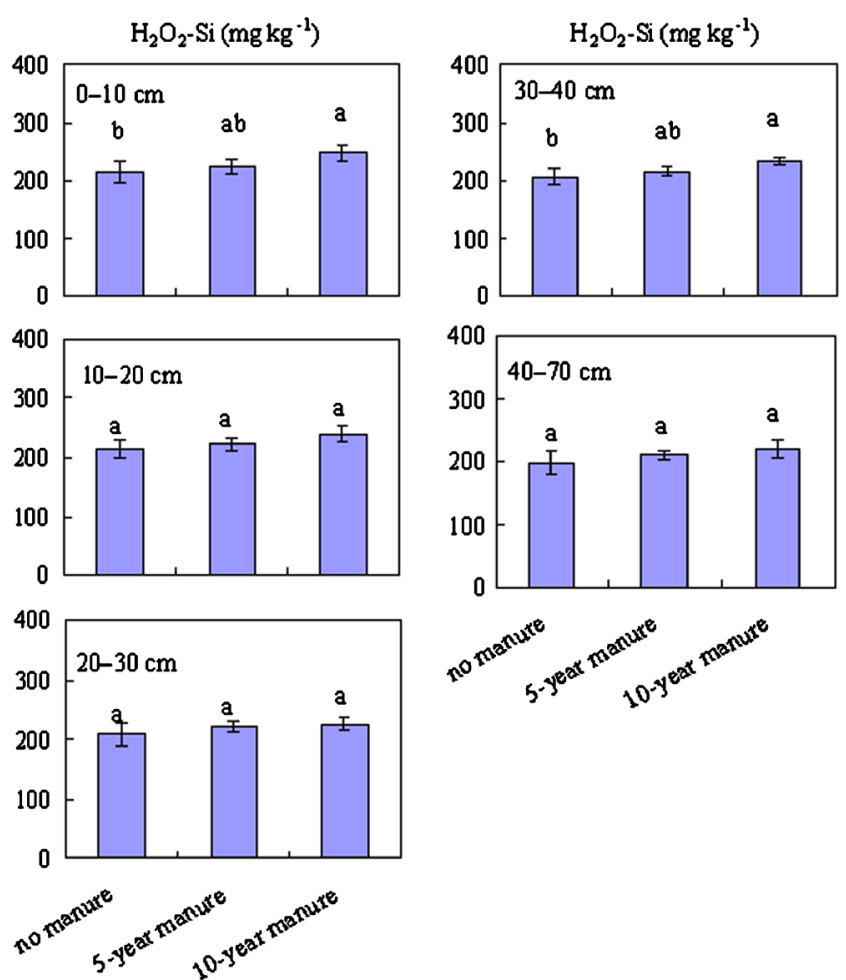

Fig. 3 Distribution of $\mathrm{H}_{2} \mathrm{O}_{2}-\mathrm{Si}$ in soils of different depths after 0 to 10 years of manure amendment. Values followed by the same letter of a soil depth within a figure are not significantly different at $P<0.05 . \mathrm{H}_{2} \mathrm{O}_{2}-$ Si content in soils of $0-40 \mathrm{~cm}$ increased from lower than 215 to $245 \mathrm{mg} \mathrm{kg}^{-1}$ with the cumulative additions of pig manure due to organic Si input from manure

$\mathrm{NaOH}-\mathrm{Si}$ content in soil profiles increased from lower than $2,800 \mathrm{mg} \mathrm{kg}^{-1}$ to higher than $3,800 \mathrm{mg} \mathrm{kg}^{-1}$ with the cumulative additions of pig manure, as is more obvious in the upper parts of soil profiles (i.e., 0 to $40 \mathrm{~cm}$ ) due to the release of amorphous Si from manure (Fig. 5). The mass ratio of acid $\mathrm{Na}$ acetate-Si $/ \mathrm{NaOH}-\mathrm{Si}$ increased from 0.046 to 0.070 with the cumulative additions of pig manure in the mid-upper parts $(0$ to $40 \mathrm{~cm}$ ) of soil profiles due to a higher dissolution rate of amorphous Si in organic materials than in soils (Fraysse et al. 2009).

\subsection{Transformation and bioavailability of manure $\mathrm{Si}$ in soils}

The distribution of noncrystalline $\mathrm{Si}$ in soil profiles (Table 2, Figs. 1, 2, 3, and 4) indicates that pig manure amendment controls the distribution, transformation, and bioavailability of manure $\mathrm{Si}$ in the upper parts from 0 to $40 \mathrm{~cm}$ depth of soil profiles.

The changes of relative bioavailability of soil $\mathrm{Si}$ with the cumulative additions of pig manure can be characterized according to the changes of acid $\mathrm{Na}$ acetate-Si percentage in noncrystalline Si (Tessier et al. 1979; Lu 2000). The relative increase in acid $\mathrm{Na}$ acetate- $\mathrm{Si}$ in the noncrystalline $\mathrm{Si}$ with cumulative additions of pig manure (Fig. 2) indicates that the bioavailability of $\mathrm{Si}$ increased with cumulative additions of pig manure.

The ratio of acid $\mathrm{Na}$ acetate-Si to other noncrystalline $\mathrm{Si}$ in soils reflects the relative bioavailability of other noncrystalline $\mathrm{Si}$ (Tessier et al. 1979; Lu 2000). The relative bioavailability of $\mathrm{H}_{2} \mathrm{O}_{2}-\mathrm{Si}, \mathrm{NH}_{2} \mathrm{OH} \cdot \mathrm{HCl}-\mathrm{Si}$, and $\mathrm{NaOH}-\mathrm{Si}$ increased with the cumulative additions of pig manure in the upper parts ( 0 to $20 \mathrm{~cm}$ ) of soil profiles from 0.62 to $1.09,0.21$ to 0.46 , and 0.046 to 0.070 , respectively (Figs. 1, 2, 3, and 4). The higher relative bioavailability of $\mathrm{H}_{2} \mathrm{O}_{2}-\mathrm{Si}$ and $\mathrm{NH}_{2} \mathrm{OH} \cdot \mathrm{HCl}-\mathrm{Si}$ than $\mathrm{NaOH}-\mathrm{Si}$ was also observed in other natural ecosystems such as rainforests (Alexandre et al. 1997; Farmer et al. 2005; Conely et al. 2008). However, the increasing trend of relative bioavailability of $\mathrm{H}_{2} \mathrm{O}_{2}-\mathrm{Si}, \mathrm{NH}_{2} \mathrm{OH} \cdot \mathrm{HCl}-\mathrm{Si}$, and $\mathrm{NaOH}-\mathrm{Si}$ with accumulation of organic matter has not been observed. This difference in relative bioavailability of $\mathrm{Si}$ between our manure amendment ecosystems with other natural ecosystems may be due to a relatively higher solubility of $\mathrm{Si}$ in manure
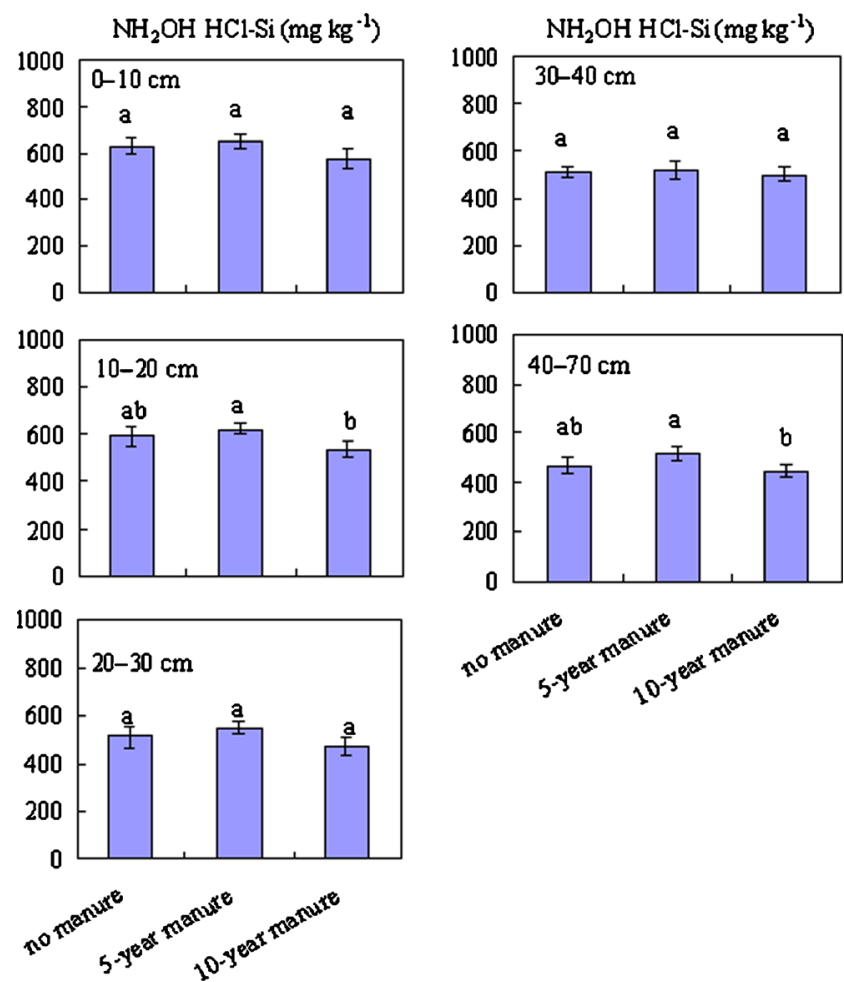

Fig. 4 Distribution of $\mathrm{NH}_{2} \mathrm{OH} \cdot \mathrm{HCl}-\mathrm{Si}$ in soils of different depths after 0 to 10 years of manure amendment. Values followed by the same letter of a soil depth within a figure are not significantly different at $P<0.05$. $\mathrm{NH}_{2} \mathrm{OH} \cdot \mathrm{HCl}-\mathrm{Si}$ content in soils of most depths except $30-40 \mathrm{~cm}$ increased slightly from lower than 620 to $650 \mathrm{mg} \mathrm{kg}^{-1}$ during the first 5 years of manure amendment due to the high efficiency of $\mathrm{Fe}-\mathrm{Mn}$ oxides in adsorption of bioavailable Si released from manure degradation and declined to lower than $570 \mathrm{mg} \mathrm{kg}^{-1}$ during the next 5 years of manure amendment due to Fe-Mn oxide dissolution under high organic acid conditions (Chen et al. 2003) created by incomplete degradation of pig manure 

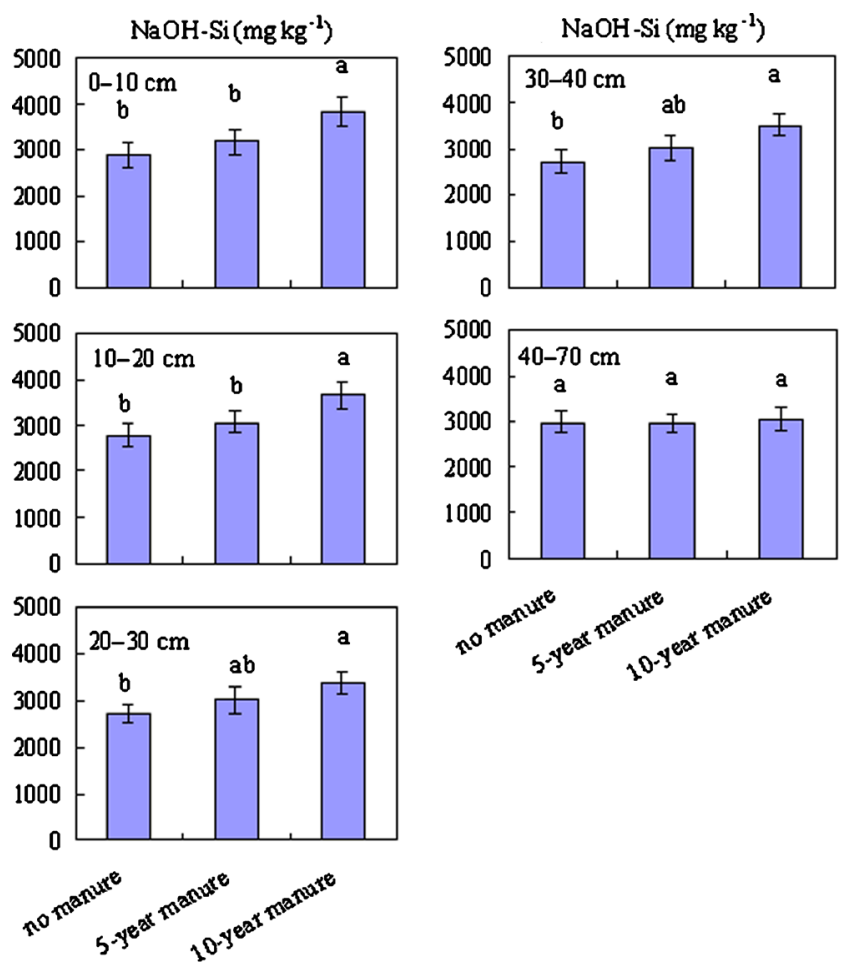

Fig. 5 Distribution of $\mathrm{NaOH}-\mathrm{Si}$ in soils of different depths after 0 to 10 years of manure amendment. Values followed by the same letter of a soil depth within a figure are not significantly different at $P<0.05$. $\mathrm{NaOH}-\mathrm{Si}$ content in soil profiles increased from lower than $2,800 \mathrm{mg} \mathrm{kg}^{-1}$ to higher than $3,800 \mathrm{mg} \mathrm{kg}^{-1}$ with the cumulative additions of pig manure due to the release of amorphous $\mathrm{Si}$ from manure

after animal digestion than in natural plant residues. However, this hypothesis requires further examination.

As annual rice removal of $\mathrm{Si}$ from soils was estimated to range 205 to $611 \mathrm{~kg} \mathrm{ha}^{-1}$ (Prakash 2002; Wickramasinghe and Rowell 2006; this study) during rice production, accumulation of bioavailable $\mathrm{Si}$, and other potential $\mathrm{Si}$ forms after manure amendment indicates that long-term pig manure amendment can ameliorate a deficiency of bioavailable $\mathrm{Si}$ in soils.

The above observations have broad implications for agricultural production and organic waste treatment. In addition to high rice residue production (about 330 million tons annually), the production of other cereal residues (such as maize residues and wheat residues) is almost equally large and has a similarly high Si content (about 5 \%) (Van Soest 2006; Wickramasinghe and Rowell 2006). All these cereal residues are the primary feed for animals in China and other cereal-producing countries (Van Soest 2006). As Si is poorly absorbed or digested by animals, the $\mathrm{Si}$ content in animal manure (5 to $20 \mathrm{~g} \mathrm{~kg}^{-1}$ total $\mathrm{Si}$ ) is almost equally high (this study; Van Soest 2006). Therefore, the animal manure from all cereal-producing areas of the world may be used to improve soil available Si content to aid cereal production while simultaneously producing an economic value in the form of animal biomass production. A new sustainable model for agricultural production and organic waste treatment can be illustrated as follows: cereal production, animal raising with cereal residues as the main feed, Si-rich animal manure production, soil incorporation of animal manure after proper treatment, and further cereal production.

\section{Conclusions}

The results of our investigation show that cumulative manure amendment may increase the content of available $\mathrm{Si}$ in soils either directly through manure available $\mathrm{Si}$ input or indirectly through mineralization and transformation of other noncrystalline $\mathrm{Si}$ forms released from manure degradation. The relative bioavailability of $\mathrm{H}_{2} \mathrm{O}_{2}-\mathrm{Si}, \mathrm{NH}_{2} \mathrm{OH} \cdot \mathrm{HCl}-\mathrm{Si}$, and $\mathrm{NaOH}-\mathrm{Si}$ increased with the cumulative additions of pig manure in the upper parts ( 0 to $20 \mathrm{~cm}$ ) of soil profiles from 0.62 to $1.09,0.21$ to 0.46 , and 0.046 to 0.070 , respectively. Long-term manure amendment can ameliorate a deficiency of bioavailable $\mathrm{Si}$ in soil. We believe that the animal manure from cereal-producing areas of the world may also be used to improve soil available Si content to aid subsequent cereal production while generating an added economic benefit in the form of animal husbandry. Our findings can offer a new sustainable model for agricultural production and organic waste treatment. However, further research is necessary to quantify the amount of animal manure required to fulfill crop Si demand and maintain available Si levels in soils of cerealproducing areas of the world.

Acknowledgments We are grateful for support from the National Natural Science Foundation of China (41103042), Program for the Distinguished Young and Middle-Aged Academic Leaders of Higher Education Institutions of Zhejiang Province (PD2013240), Program for the Top Young Talents of Zhejiang Agricultural and Forestry University, and the Field Frontier Project of Institute of Geochemistry, Chinese Academy of Sciences.

Conflict of interest The authors have declared no conflict of interest.

\section{References}

Alexandre A, Meunier JD, Colin F, Koud JM (1997) Plant impact on the biogeochemical cycle of silicon and related weathering processes. Geochim Cosmochim Acta 61:677-682. doi:10.1016/S00167037(97)00001-X

Chen J, Gu BH, Royer RA (2003) The roles of natural organic matter in chemical and microbial reduction of ferric iron. Sci Total Environ 307:167-178. doi:10.1016/S0048-9697(02)00538-7

Conley DJ, Liken G, Buso DC, Saccone L, Bailey SW, Johnson CE (2008) Deforestation causes increased dissolved silicate losses in the Hubbard Brook Experimental Forest. Glob Chang Biol 14:25482554. doi:10.1111/j.1365-2486.2008.01667.x

Cornelis J-T, Titeux H, Ranger J, Delvaux B (2010) Identification and distribution of the readily soluble silicon pool in a temperate forest soil below three distinct tree species. Plant Soil 342:369-378. doi: 10.1007/s11104-010-0702-x 
Farmer VC, Delbos E, Miller JD (2005) The role of phytolith formation and dissolution in controlling concentrations of silica in soil solutions and streams. Geoderma 127:71-79. doi:10.1016/j.geoderma. 2004.11.014

Fraysse F, Pokrovsky OS, Schott J, Meunier J-D (2009) Surface chemistry and reactivity of plant phytoliths in aqueous solutions. Chem Geol 258:197-206. doi:10.1016/j.chemgeo.2008.10.003

Gong H, Zhu X, Chen K, Wang S, Zhang C (2005) Silicon alleviates oxidative damage of wheat plants in pots under drought. Plant Sci 169:313-321. doi:10.1016/j.plantsci.2005.02.023

Höhn A, Sommer M, Kaczorek D, Schalitz G, Breuer J (2008) Silicon fractions in Histosols and Gleysols of a temperate grassland site. J Plant Nutr Soil Sci 171:409-418. doi:10.1002/jpln.200625231

Kögel-Knabner I, Amelung W, Cao Z, Fiedler S, Frenzel P, Jahn R, Kalbitz K, Kölbl A, Schloter M (2010) Biogeochemistry of paddy soils. Geoderma 157:1-14. doi:10.1016/j.geoderma. 2010.03.009

Kurtz C, Derry LA, Chadwick OA (2002) Germanium/silicon fractionation in the weathering environment. Geochim Cosmochim Acta 66: 1525-1537. doi:10.1016/S0016-7037(01)00869 -9

Liang Y, Wong JWC, Wei L (2005) Silicon-mediated enhancement of cadmium tolerance in maize (Zea mays L.) grown in cadmium contaminated soil. Chemosphere 58:475-483. doi:10.1016/j. chemosphere.2004.09.034

Lu RK (2000) Methods of soil agricultural chemical analysis. China Agricultural Science and Technology, Beijing (in Chinese)

Ma JF, Takahashi E (1991) Effect of silicate on phosphate availability for rice in a P-deficient soil. Plant Soil 133:151-155. doi:10.1007/ BF00009187

Matichenkov VV, Calvert DV (2002) Silicon as a beneficial element for sugarcane. J Am Soc Sugar Tech 22:21-30

Mortlock RA, Froelich PN (1989) A simple method for the rapid determination of biogenic opal in pelagic marine sediments. Deep Sea Res 36:1415-1426. doi:10.1016/0198-0149(89)90092-7

Murphy J, Riley JP (1962) A modified single solution for the determination of phosphorus in natural waters. Anal Chim Acta 27:31-36. doi: 10.1016/S0003-2670(00)88444-5

Nakata Y, Ueno M, Kihara J, Ichii M, Taketa S, Arase S (2008) Rice blast disease and susceptibility to pests in a silicon uptake-deficient mutant lsil of rice. Crop Prot 27:865-868. doi:10.1016/j.cropro. 2007.08.016

Nelson RE, Sommers LE (1982) Total carbon, organic carbon, and organic matter. In: Page AL, Miller RH, Keeney DR (eds) Methods of soil analysis, part 2, 2nd edn. Agron. Monogr. 9. ASA and SSSA, Madison, pp 539-579

Prakash N.B. (2002) Status and utilisation of silicon in Indian rice farming. In: Proceedings of the second silicon in agriculture conference, Tsuruoka, Yamagata, Japan. Japanese Society of Soils and Plant Nutrition, pp. 266-273

Richmond KE, Sussman M (2003) Got Silicon? The non-essential beneficial plant nutrient. Curr Opin Plant Biol 6:268-272. doi:10.1016/ S1369-5266(03)00041-4

Rodrigues FÁ, Vale FXR, Korndörfer GH, Prabhu AS, Datnoff LE, Oliveira AMA, Zambolim L (2003) Influence of silicon on sheath blight of rice in Brazil. Crop Prot 22:23-29. doi:10.1016/S02612194(02)00084-4

Savant NK, Snyder GH, Datnoff LE (1997) Silicon management and sustainable rice production. Adv Agron 58:151-199. doi:10.1016/ S0065-2113(08)60255-2

Sommer M, Kaczorek D, Kuzyakov Y, Breuer J (2006) Silicon pools and fluxes in soils and landscapes - a review. J Plant Nutr Soil Sci 169: 310-329

Tessier A, Campbell PGC, Bisson M (1979) Sequential extraction procedure for the speciation of particulate trace metals. Anal Chem 51: 844-851. doi:10.1021/ac50043a017

Tuna L, Kaya C, Higgs D, Murillo-Amador B et al (2008) Silicon improves salinity tolerance in wheat plants. Environ Exp Bot 62: 10-16. doi:10.1016/j.envexpbot.2007.06.006

Van der Vorm PDJ (1980) Uptake of Si by five plant species as influenced by variation in Si supply. Commun Soil Sci Plant Anal 21:153-156

Van Soest PJ (2006) Rice straw, the role of silica and treatments to improve quality. Anim Feed Sci Techn 130:137-171. doi:10.1016/ j.anifeedsci.2006.01.023

White AF, Blum AE (1995) Effects of climate on chemical weathering in watersheds. Geochim Cosmochim Acta 59:1729-1747

Wickramasinghe DB, Rowell DL (2006) The release of silicon from amorphous silica and rice straw in Sri Lankan soils. Biol Fert Soils 42:231-240. doi:10.1007/s00374-005-0020-2 